удк 349.1

\author{
Ю. Б. Костюк \\ аспірант кафедри адміністративно-правових дисииплін \\ юридичного факультету \\ Львівського державного університету внутрішніх справ
}

\title{
СТАНОВЛЕННЯ ТА РОЗВИТОК ДЕРЖАВНОЇ ВЕТЕРИНАРНОЇ СЛУЖБИ В УКРАЇНІ
}

Здійснення державного ветеринарно-санітарного контролю є одним з основних факторів забезпечення епізоотичного благополуччя і продовольчої безпеки нашої держави. Органи державної влади, які здійснюють ветеринарносанітарний контроль, забезпечують контроль та нагляд у багатьох галузях тваринництва, а також виробництва й обігу харчових продуктів. Зокрема, такий вид державного контролю здійснюється на фермах, приватних господарствах, агропромислових ринках, підприємствах, що виробляють та реалізують харчові продукти. Окрім цього, державний ветеринарний контроль проводиться на державному кордоні, під час внутрішньодержавних перевезень тварин і продукції тваринництва, а також у лісництвах та національних природних парках. Таким чином, система державного ветеринарно-санітарного контролю охоплює широкий спектр державного управління, починаючи від вирощування продуктивних тварин і закінчуючи реалізацією готової харчової продукції. На нашу думку, аналіз основних етапів становлення та розвитку державної ветеринарної служби в Україні необхідний для визначення перспектив подальшого розвитку галузі, особливо в контексті гармонізації чинного українського законодавства із законодавством Європейського Союзу.

Незважаючи на широке коло наукових досліджень різних сфер діяльності органів виконавчої влади, робота державної ветеринарної служби є не досить дослідженою. Різні аспекти діяльності в галузі ветеринарної медицини вивчали В.Б. Авер'янов, П.І. Вербицький, П.П. Достоєвський, С.К. Рудик, Н.М. Мельникова, Д.О. Мельничук та інші вчені. Однак при цьому до цього часу залишається актуальним питання перспектив розвитку державної ветеринарної служби в Україні, яке потребує додаткового аналізу та вивчення.

Метою статті є аналіз законодавства України в частині діяльності центральних органів виконавчої влади, які здійснюють повноваження в галузі державного ветеринарно-санітарного контролю та нагляду, а також дослідження сфери повноважень цих органів виконавчої влади.

Нині законодавство України переживає системну трансформацію, відбуваються зміни в системі державного управління, в тому числі в галузі ветеринарної медицини. Сформувати досконалий апарат державного управління та створити надійне ветеринарне законодавство неможливо без всебічного врахування величезного досвіду законодавчого забезпечення ветеринарної справи в Україні на різних етапах ï історичного розвитку [1, с. 379]. Починаючи від прийняття першої редакції Закону України «Про ветеринарну медицину» 25 червня 1992 року Закон мав декілька редакцій із суттєвими змінами, а структура державної ветеринарної служби декілька разів змінювала свій формат. При цьому вищезазначений Закон є чинним дотепер, а державна ветеринарна служба функціонує в структурі Державної служби України з питань безпечності харчових продуктів та захисту споживачів. Вивчення становлення і розвитку державної служби ветеринарної медицини є важливим питанням щодо аналізу здійснення адміністративно-правового регулювання галузі ветеринарної медицини, а також моделювання ï майбутнього розвитку.

Україна по праву вважається державою з розвинутим тваринництвом і традиційно високим рівнем виробництва тваринної продукції. Для регулювання аграрної галузі загалом і тваринництва зокрема в Україні здійснюються заходи державного контролю за дотриманням законодавства в галузі ветеринарної медицини. Оскільки ця сфера пов'язана з багатьма ключовими питаннями безпеки держави, розвиток тваринництва, виробництво харчових продуктів, охорона здоров'я людей і тварин (епізоотична безпека), вивчення системи державних органів ветеринарної медицини, їх становлення та розвиток є необхідною передумовою для якісного юридичного забезпечення цієї галузі.

Функції державної ветеринарної служби в Україні у різні періоди виконували різні компетентні органи виконавчої влади. Становлення і розвиток державної ветеринарної служби України, як і багатьох інших органів виконавчої влади, доцільно розглядати від дати створення новітньої Української держави - 24 серпня 1991 року. 3 огляду на те, що, перебуваючи в складі Радянського Союзу, органи державної влади Української Радянської Соціалістичної Республіки були повністю залежні від управління Союзу Радянських Соціалістичних Республік, у цій статті радянський період залишимо поза увагою.

Першим законодавчим актом незалежної України, який стосувався безпосередньо здійснення ветеринарно-санітарного контролю, став 
Закон України «Про ветеринарну медицину» від 25 червня 1992 року [2]. Закон визначав основні завдання ветеринарної медицини, містив положення щодо наукової діяльності, роботи спеціалістів, а також роботи державних органів ветеринарної медицини загалом. Варто відзначити, що Закон «Про ветеринарну медицину» 1992 року зі змінами $є$ чинним на момент написання цієї статті, і відповідно, є одним із найдавніших чинних законодавчих актів незалежної України.

Відповідно до першої редакції Закону ветеринарна медицина визначалась як комплекс заходів щодо профілактики захворювань тварин, їх лікування, скорочення втрат від хвороб, неплідності і падежу, підвищення якості сировини і продуктів тваринного походження, попередження та боротьби 3 хворобами, спільними для тварин і людей, одержання екологічно чистих продуктів харчування. Щодо визначення терміна державний ветеринарний контроль, то цим терміном позначалась діяльність органів державної ветеринарної медицини з виконання ветеринарних вимог під час виробництва, переробки, зберігання, транспортування тварин та сировини і продуктів тваринного походження, виробництва та використання імунобіологічних, біологічних, рослинних, хімічних, хіміко-фармацевтичних препаратів, а також з додержання правил утилізації загиблих тварин.

Стаття 2 Закону «Про ветеринарну медицину» в першій редакції визначала такі основні завдання ветеринарної медицини: профілактика, діагностика, лікування інфекційних, інвазійних і незаразних хвороб свійських тварин та дикої фауни, контроль за випуском для реалізації доброякісних у ветеринарному відношенні продуктів і сировини тваринного походження, захист населення від хвороб, спільних для тварин і людей, охорона території України від занесення інфекційних хвороб тварин з територій інших держав, контроль за переміщенням, експортом та імпортом сировини і тварин, продукції тваринного походження, ветеринарно-санітарна експертиза продуктів тваринного і рослинного походження, контроль за якістю виробництва лікувальних, діагностичних, профілактичних засобів та кормових добавок, призначених для ветеринарної медицини, радіологічний і токсикологічний контроль продуктів тваринного і рослинного походження на ринках, м'ясокомбінатах, холодильниках та базах по заготівлі, зберіганню і реалізації продуктів тощо, проведення незалежної ветеринарно-санітарної експертизи продуктів, сировини і тварин, продукції тваринного походження, кормів, препаратів для цілей ветеринарної медицини у разі ї експорту та імпорту, контроль за додержанням юридичними та фізичними особами ветеринарно-санітарних вимог, спрямованих на захист навколишнього природного середовища. Окремо було виділено завдання державних органів ветеринарної медицини - впроваджувати на практиці новітні досягнення ветеринарної науки.

Таким чином, до основних завдань ветеринарної медицини було віднесено не лише контроль та нагляд за станом здоров'я живих тварин, але і забезпечення безпечності харчових продуктів, кормів і сировини тваринного походження. На державну ветеринарну службу було покладено завдання також щодо контролю імпорту, експорту та транзиту підконтрольних продуктів (в т.ч. живих тварин) із правом видачі відповідних ветеринарних документів, контролю за виробництвом і розповсюдженням продуктів тваринного походження, дотримання правил вирощування (розведення) тварин.

Систему державних органів ветеринарної медицини України, згідно з першою редакцією Закону України «Про ветеринарну медицину», становили: Головне управління ветеринарної медицини 3 державною ветеринарною інспекцією Міністерства сільського господарства і продовольства України $з$ підпорядкованими йому Кримським республіканським, обласними, Київським та Севастопольським міськими управліннями державної ветеринарної медицини. Головному управлінню підпорядковувались Центральна лабораторія ветеринарної медицини, зональні спеціалізовані лабораторії ветеринарної медицини по хворобах тварин, міжобласні спеціалізовані державні лабораторії ветеринарної медицини по хворобах птиці. До складу Головного управління входила також державна корпорація «Укрзооветпромпостач», а також підприємства 3 виробництва імунобіологічних, хіміко-фармацевтичних ветеринарних препаратів, приладів, обладнання та інструментів. Окремо варто відзначити Державний науково-дослідний контрольний інститут ветеринарних препаратів і кормових добавок, який є єдиним державним органом, що здійснює державну реєстрацію ветеринарних препаратів і кормів.

Окрім вищезазначених суб'єктів, у структуру Головного управління входили служби державної ветеринарної медицини на залізницях та прикордонних контрольних пунктах ветеринарної медицини, а також відділення відомчої ветеринарної міліції із забезпечення карантинних ветеринарних заходів.

20 листопада 1992 року було прийнято Постанову Кабінету Міністрів України № 629 «Питання Головного управління ветеринарної медицини з державною ветеринарною інспекцією Міністерства сільського господарства і продовольства» [3], якою було затверджено Положення про Головне управління ветеринарної медицини з державною ветеринарною інспекцією Міністерства сільського господарства і продовольства.

Варто відзначити певну особливість структури державної ветеринарної служби, яка була характерна лише для пострадянських країн, 
а саме наявність в її складі ветеринарної міліції. В частині 4 Положення про Головне управління ветеринарної медицини 3 державною ветеринарною інспекцією Міністерства сільського господарства і продовольства було вказано таке: Головне управління відповідно до покладених на нього завдань безпосередньо, а також через підпорядковані йому органи й установи координує і контролює роботу відділів відомчої ветеринарної міліції, пов'язану із забезпеченням проведення карантинних заходів. Управління ветеринарної міліції були самостійними структурними підрозділами MBC, які організаційно підпорядковувались одному із заступників Міністра внутрішніх справ згідно з розподілом обов' язків, а функціонально Головному управлінню ветеринарної медицини з державною ветеринарною інспекцією Міністерства сільського господарства і продовольства.

3 часом було прийнято окремий нормативноправовий акт, який регламентував роботу підрозділів ветеринарної міліції, а саме Постанову Кабінету Міністрів України «Про затвердження Положення про підрозділи ветеринарної міліції 3 проведення карантинних ветеринарних заходів» від 29 березня 2002 року № 395 [4]. Згідно 3 частиною 3 Постанови зазначалося, що управління ветеринарної міліції є самостійним структурним підрозділом МВС, який організаційно підпорядковується одному із заступників Міністра внутрішніх справ згідно з розподілом обов'язків, а функціонально - Держветфітослужбі. Територіальні підрозділи ветеринарної міліції організаційно підпорядковуються заступникам начальників головних управлінь, управлінь МBC в Автономній Республіці Крим, областях, містах Києві та Севастополі, міських і районних відділів (управлінь) внутрішніх справ, а функціонально начальникам відповідних територіальних органів Держветфітослужби. Ця Постанова КМУ втратила чинність лише 21 серпня 2015 року. Відповідно, всі підрозділи ветеринарної міліції на теритоpiї України були ліквідовані.

Відповідно до Постанови Кабінету Міністрів України «Питання Державного департаменту ветеринарної медицини» від 17 листопада 1997 року № 1277 [5] на базі Головного управління ветеринарної медицини 3 державною ветеринарною інспекцією Міністерства сільського господарства і продовольства було створено Державний департамент ветеринарної медицини Міністерства агропромислового комплексу України. Державний департамент ветеринарної медицини став правонаступником прав і обов'язків ліквідованого Головного управління ветеринарної медицини з державною ветеринарною інспекцією Міністерства сільського господарства і продовольства.

Наступним етапом діяльності державної ветеринарної служби стало створення центрального органу виконавчої влади - Державного комітету ветеринарної медицини. Постановою Кабінету Міністрів України «Питання Державного департаменту ветеринарної медицини» від 30 серпня 2007 року № 1075 [6] було реорганізовано Державний департамент ветеринарної медицини шляхом перетворення його у центральний орган виконавчої влади - Державний комітет ветеринарної медицини України. В Положенні про Державний комітет ветеринарної медицини України було зазначено, що Держкомветмедицини є центральним органом виконавчої влади, діяльність якого спрямовується і координується Кабінетом Міністрів України через Міністра аграрної політики.

Черговим наступним етапом стало створення Державної ветеринарної та фітосанітарної служби України. Згідно з Указом Президента України «Про оптимізацію системи центральних органів виконавчої влади» від 9 грудня 2010 року № 1085/2010 [7], було реорганізовано Державний комітет ветеринарної медицини України в Державну ветеринарну та фітосанітарну служби України з покладанням на неї, окрім діяльності в галузі ветеринарної медицини, також функцій з реалізації державної політики у сфері захисту рослин. Державна ветеринарна та фітосанітарна служба України знову ж таки була центральним органом виконавчої влади України, діяльність якого спрямовувалася Кабінетом Міністрів України через Міністерство аграрної політики та продовольства України. Держветфітослужба України входила до системи органів виконавчої влади і забезпечувала реалізацію державної політики у галузі ветеринарної медицини, безпечності харчових продуктів, сферах карантину та захисту рослин, охорони прав на сорти рослин, державного нагляду (контролю) за племінною справою у тваринництві. Голова Державної ветеринарної та фітосанітарної служби України за посадою виконував функції Головного державного інспектора ветеринарної медицини України.

Останнім етапом розвитку і переформатування державної ветеринарної служби в незалежній Україні стало створення Державної служби України з питань безпечності харчових продуктів та захисту споживачів. Ця установа була створена згідно з Постановою Кабінету Міністрів України «Про оптимізацію системи центральних органів виконавчої влади» від 10 вересня 2014 року № 442 [8]. Державну службу України з питань безпечності харчових продуктів та захисту споживачів було створено на базі Державної ветеринарної та фітосанітарної служби із приєднанням Державної інспекції з питань захисту прав споживачів і Державної санітарно-епідеміологічної служби. На новостворену Держпродспоживслужбу було покладено функції з реалізації державної 
політики в галузях, які здійснювали вищезазначені реорганізовані органи виконавчої влади.

Усі зазначені нами державні органи виконували в певні періоди часу функції координації та забезпечення реалізації державної політики в галузі ветеринарно-санітарного нагляду та контролю на території України, а саме: охорона території України від проникнення хвороб тварин з території інших держав або карантинних зон, захист тварин та населення від збудників та хвороб тварин шляхом здійснення профілактичних, діагностичних та лікувальних заходів, здійснення заходів унеможливлення перенесення хвороб тварин через товари, засоби догляду за тваринами і супутні об'єкти, встановлення ефективних та дієвих засобів виявлення, локалізації, контролю і за можливості ліквідації ендемічних хвороб тварин та ліквідації екзотичних хвороб тварин, занесених на територію України, забезпечення надійних та ефективних заходів ліквідації спалахів хвороб тварин з метою зменшення втрат тварин, а в разі зоонозів - зменшення ризику для людей.

Державні органи ветеринарної медицини здійснювали та здійснюють нині моніторинг кормів та води для забезпечення їх придатності для вживання та неможливості перенесення хвороб тварин, забезпечення правильного, належного, ефективного та безпечного застосування ветеринарних препаратів, захист навколишнього природного середовища від негативних наслідків, що пов'язані з вирощуванням та обігом тварин, захист благополуччя тварин шляхом забезпечення гуманного ставлення до них протягом усього їхнього життя, здійснення передзабійного клінічного огляду тварин та проведення ветеринарно-санітарної експертизи продуктів тваринного походження, у тому числі тварин, забитих на полюванні, включаючи бактеріологічні, радіологічні, паразитологічні та токсикологічні лабораторні дослідження, здійснення державного ветеринарно-санітарного контролю та нагляду в процесі виробництва й обігу продуктів тваринного походження, ветеринарних препаратів, субстанцій, кормових добавок, преміксів, кормів, штамів мікроорганізмів, репродуктивного і патологічного матеріалу та здійснення державного ветеринарно-санітарного нагляду під час обігу засобів ветеринарної медицини та засобів догляду за тваринами, здійснення моніторингу залишкових кількостей ветеринарних препаратів та інших забруднюючих речовин у тваринах, продуктах тваринного походження i кормах, здійснення стандартного прикордонного ветеринарно-санітарного контролю та/або розширеного ветеринарно-санітарного контролю за об'єктами державного ветеринарно-санітарного контролю та нагляду, контроль за переміщенням об’єктів державного ветеринарно-санітарного контролю та нагляду в межах України тощо.
Загалом, робота державної ветеринарної служби є важливим фактором забезпечення стабільної епізоотичної та економічної ситуації в країні. Становлення і розвиток державної ветеринарної служби, як ми побачили, розпочинається з часів незалежності України та умовно складається з п'яти основних етапів. Ці етапи відповідають періодам діяльності п'яти центральних органів виконавчої влади, уповноважених здійснювати державний ветеринарносанітарний контроль та нагляд, які створювались та розформовувались згідно з постановами Кабінету Міністрів України та в одному окремому випадку згідно з Указом Президента України. Перерахуємо окремо в хронометричному порядку ці центральні ограни виконавчої влади: Головне управління ветеринарної медицини 3 державною ветеринарною інспекцією Міністерства сільського господарства і продовольства; Державний департамент ветеринарної медицини Міністерства агропромислового комплексу України; Державний комітет ветеринарної медицини України; Державна ветеринарна та фітосанітарна служба України; Державна служба України з питань безпечності харчових продуктів та захисту споживачів.

Виконання функцій цих органів забезпечували державні інспектори ветеринарної медицини, лікарі ветеринарної медицини, ветеринарні лікарі та фельдшери, лаборанти, санітари та інший персонал. Роботу державних ветеринарних відомств очолював керівник - Головний державний інспектор ветеринарної медицини України. Нині Головний державний інспектор ветеринарної медицини очолює Департамент безпечності харчових продуктів та ветеринарії, однак при цьому підпорядковується Голові Державної служби України з питань безпечності харчових продуктів та захисту споживачів.

Варто звернути увагу, що структура цих органів державної влади залежала від загального вектора зовнішньої політики держави. Як і в інших основних питаннях державної політики, ці напрями зовнішньої політики можна умовно розділити на «східний» та «західний». Відповідно, робота державних органів при «східному» (російському) напрямі була зорієнтована на співпрацю в рамках Митного союзу, а робота при «західному» (європейському) напрямі передбачає орієнтацію на стандарти європейських країн. Так, створена в 2010 році Державна ветеринарна та фітосанітарна служба за своєю структурою і функціями мала спільні риси 3 аналогічним органом виконавчої влади Російської Федерації. Теперішня ж структура, а саме Державний департамент ветеринарної медицини та безпечності харчових продуктів у структурі Держпродспоживслужби України, створено згідно 3 моделлю країн-членів Свропейського Союзу.

Враховуючи загальний європейський вектор розвитку країни, наближення українського законодавства, у тому числі в сфері ветеринарної 
медицини, до законодавства Свропейського Союзу $€$ логічним етапом сучасного розвитку нашої держави. Введення нових правових норм, визнання еквівалентності законодавства країн Європейського співтовариства та створення нових органів виконавчої влади відбувається саме в рамках виконання Україною положень Угоди про асоціацію між Україною, з однієї сторони, та Європейським Союзом, Європейським співтовариством 3 атомної енергії i їхніми державами-членами, з іншої сторони.

Натепер на законодавчому рівні було створено всі передумови для забезпечення функціонування державної ветеринарної служби згідно з кращими європейськими аналогами. Разом із тим таке функціонування стане можливим лише за умови додержання ветеринарного законодавства, а також за належного державного фінансування цієї галузі.

\section{Iimepamypa}

1. Довгань B.I. Історичний контекст становлення державного управління у галузі ветеринарної медицини. Університетські наукові записки: наукове видання Хмельницького університету управління та права, 2011. № 2. C. 379-388.

2. Про ветеринарну медицину : Закон України від 25 червня 1992 р. № 2498-XII. URL: https:// zakon.rada.gov.ua/laws/show/2498-12/ed19920625 (дата звернення: 03.05.2019).

3. Питання Головного управління ветеринарної медицини 3 державною ветеринарною інспекцією Міністерства сільського господарства і продовольства : Постанова Кабінету Міністрів України від 20 листопада 1992 p. № 629. URL: https://zakon.rada.gov.ua/laws/ show/629-92 (дата звернення: 03.05.2019).

4. Про затвердження Положення про підрозділи ветеринарної міліції з проведення карантинних ветеринарних заходів : Постанова Кабінету Міністрів України від 29 березня 2002 р. № 395. URL: https:// zakon.rada.gov.ua/laws/show/395-2002 (дата звернення: 04.05.2019).

5. Питання Державного департаменту ветеринарної медицини:ПостановаКабінетуМіністрівУкраїнивід 17листопада 1997 р. № 1277. URL: https://zakon.rada.gov.ua/ laws/show/1277-97 (дата звернення: 04.05.2019).

6. Питання Державного департаменту ветеринарної медицини : Постанова Кабінету Міністрів України від 30серпня 2007p.№1075.URL:https://zakon.rada.gov.ua/ laws/show/1075-2007 (дата звернення: 04.05.2019).

7. Про оптимізацію системи центральних органів виконавчої влади : Указ Президента України від 9 грудня 2010 p. № 1085/2010. URL: https://zakon.rada.gov.ua/ laws/show/1085/2010 (дата звернення: 06.05.2019).

8. Про оптимізацію системи центральних органів виконавчої влади : Постанова Кабінету Міністрів України від 10 вересня 2014 р. № 442. URL: https:// zakon.rada.gov.ua/laws/show/442-2014 (дата звернення: 04.05.2019).

\section{Анотація}

Костюк Ю. Б. Становлення та розвиток державної ветеринарної служби в Україні. - Стаття.

Державна служба ветеринарної медицини є важливим складником виконавчої гілки державної влади, оскільки саме ця служба здійснює контроль та нагляд у сфері тваринництва, виробництва та реалізації хар- чової продукції, імпорту та експорту продукції та сировини тваринного походження тощо. Від злагодженої роботи ветеринарної служби залежить епізоотичне благополуччя та продовольча безпека держави. Юридичний аналіз становлення державної ветеринарної служби в Україні дає змогу простежити основні позитивні та негативні моменти ії формування, а також визначити перспективи подальшого розвитку.

Не зважаючи на те, що державний контроль у галузі ветеринарної медицини поширюється на широке коло фізичних та юридичних осіб, робота державної служби ветеринарної медицини та зокрема їі становлення та розвиток $€$ темою не досить вивченою науковцями. Серед учених, які займались вивченням цього питання, можна виділити В.Б. Авер'янова, П.І. Вербицького, П.П. Достоєвського, С.К. Рудика, Н.М. Мельникова, Д.О. Мельничука.

Метою дослідження $\epsilon$ аналіз становлення державної ветеринарної служби, враховуючи хронологію виникнення центральних органів виконавчої влади, уповноважених на виконання відповідних функцій. Такий аналіз проведено для виявлення як позитивних, так і негативних факторів роботи державної ветеринарної служби в Україні, а також для прогнозування подальшої роботи ветеринарної служби в рамках виконання положень Угоди про асоціацію між Україною, з однієї сторони, та Європейським Союзом, Європейським співтовариством з атомної енергії і їхніми державами-членами, з іншої сторони.

У статті здійснено аналіз основних етапів становлення та розвитку державної ветеринарної служби в Україні. Проведено аналіз основних нормативно-правових актів, які стосуються діяльності державної ветеринарної служби, в контексті наближення українського законодавства у сфері ветеринарної медицини до законодавства Європейського Союзу. Розглянуто шлях розвитку державної ветеринарної служби за період від проголошення Акта незалежності України 24 серпня 1991 року і дотепер.

Ключові слова: адміністративне право, ветеринарно-санітарний контроль.

\section{Summary}

Kostyuk Yu. B. Incipience and development of the State veterinary service in Ukraine. - Article.

State veterinary medicine service is an important component of the executive branch of government, as it provides such activities as control and supervision of livestock production, production and distribution of food products, import and export of products and raw materials of animal origin, etc. The epizootic welfare and food security of the whole country depends on the clear functioning of the veterinary service. The legal analysis of the state veterinary service in Ukraine allows us to underline the main positive and negative moments of its formation, as well as to determine the prospects of further development.

Despite the fact that state veterinary control extends to a wide range of individuals and legal entities, the work of the state veterinary service, and in particular its formation and development, is a topic that is insufficiently studied by scholars. Among the scientists who were engaged in the study of this issue can be distinguished V.B. Averyanov, P.I. Verbitsky, P.P. Dostoevsky, S.K. Rudyk, N.M. Melnikova, D.O. Melnichuk.

The main purpose of this article is to analyze formation of the State veterinary service, taking into account the chronology of the emergence of central executive authorities empowered to perform the relevant functions. This analysis was conducted to identify both the positive and the negative factors of the functioning of the state 
veterinary service in Ukraine, as well as to predict the further work of the veterinary service within the framework of implementation provisions of the Association Agreement between the European Union and the European Atomic Energy Community and their member states, of the one part, and Ukraine, of the other part.

In the article was made analysis of the main stages of formation and development of the State veterinary service in Ukraine. The evaluation of the basic legal acts concern- ing activity of the State veterinary service in context of approximation of Ukrainian legislation in the field of veterinary medicine to the legislation of the European Union has been carried out. In the article was reviewed the way of development of the state veterinary service, since the proclamation of the Act of Independence of Ukraine from August 24, 1991 to present days.

Key words: administrative law, veterinary and sanitary control. 